\title{
Financial Delinquency: Overarching Personality Dispositions and Circumstantial Risk Factors
}

\author{
Ronit Peled-Laskov'1, Yuval Wolf ${ }^{2}$ \\ ${ }^{1}$ Ashkelon Academic College, Ashkelon, Israel \\ ${ }^{2}$ Bar-Ilan University, Ramat Gan, Israel \\ Email: peleronit@gmail.com
}

How to cite this paper: Peled-Laskov, R., \& Wolf, Y. (2021). Financial Delinquency: Overarching Personality Dispositions and Circumstantial Risk Factors. Psychology, 12, 269-284.

https://doi.org/10.4236/psych.2021.122017

Received: December 25, 2020

Accepted: February 23, 2021

Published: February 26, 2021

Copyright $\odot 2021$ by author(s) and Scientific Research Publishing Inc. This work is licensed under the Creative Commons Attribution International License (CC BY 4.0).

http://creativecommons.org/licenses/by/4.0/

\begin{abstract}
This study exemplifies the viability of combined account, personality and circumstantial factors, for financial delinquency. The participants were 29 senior administrative officers (men) who have access to monetary operations in their organization. Each of them responded, via the telephone, to a type A-B questionnaire and a questionnaire which measured three personality syndromespsychopathy, narcissism and Machiavellianism, known as the "dark triad". The circumstantial part of the design, which was tested in the same meeting, was Anderson's functional measurement of the three components of Cressey's crime model-financial difficulty, opportunity for a delinquent financial decision, and rationalization. Meaningful connections were found between Type A-B and the crime model.
\end{abstract}

\section{Keywords}

White-Collar Crime, Financial Delinquency, Type A-B, Functional Measurement

\section{Introduction}

This study attempts to shed some psychological light on one facet of the field called white-collar offenses, i.e., financial delinquency. The focus is on financiers' decisions, purported to yield unlawful personal profits. While the topic of financial delinquency, especially by financiers in high-volume organizations, has been covered extensively by the mass media and to some extent in the scientific literature, it is hard to find an overarched approach to this phenomenon. Attempts to study personality traits of potential lawbreakers or predispositions of 
already caught delinquents usually do not take into account circumstantial aspects of such decisions and acts. Situational facets of related acts, such as financial problems of the beholder, an opportunity to make "safe" theft and personally viable rationalization for such an act, are operationalized and measured independently. These two generalized categories of psychological causes for financiers' delinquent decisions, predispositions and circumstantial factors, are treated in the present study under the same methodological umbrella in a way which exemplifies how an overarched account can be modelled and operationalized.

\subsection{White-Collar Financial Offenses}

No single definition of white-collar crime can be found in the literature, nor is there a consensus regarding its interpretation (Ragatz \& Fremouw, 2010). Ever since the term was coined by Sutherland (1939) various definitions have been proposed attesting to the complexity of the phenomenon. According to Mann (1990), the term white-collar crime generates a prototype based on a set of parameters: the social status of the offender, misuse of a corporate position, use of camouflage and means of deception, economic damage, and perpetration of the offense in either an organizational framework or privately-together comprising a distinct phenomenon.

In addition to the common use of the term white-collar crimes (Braithwaite, 1985), other terms are used by some, such as economic crimes (Lindström, 2004), corporate crimes (e.g. Hartley, 2008) and business crimes (e.g. Clarke, 1990). White-collar crime generally hold positions that provide them with an opening for committing crimes in which the lure is substantial monetary gains. Whitecollar crimes are sophisticated, have few pursuers, and usually involve anonymous collaborators. Discovery of the felony takes time, while the tendency exists to wrap up such cases within organizations themselves (Xie, 2015).

White-collar crimes results in considerable economic damage. In the USA it is estimated to range from $\$ 500$ billion to one trillion dollars a year (Friedrichs, 2007). Apart from the huge financial loss, it causes untold damage and suffering to the victims, while possibly also affecting the trust the public places in financial institutions, especially where corporations are involved (Ashforth \& Anand, 2003; Friedrichs, 2004).

Researchers face considerable challenges in investigating white-collar crime. White-collar criminals are not readily accessible for the purposes of research, so that the research samples are often relatively small (e.g. Gottschalk, 2019). Also, since many white-collar offenders who participate in research are under the supervision of law enforcement agencies, their testimonies jeopardize the internal validity of the study (Nee et al., 2019).

Individuals' financial decision-making is assumingly affected by several psychological factors, including intelligence, ability to make rational decisions, and personality traits (Patterson \& Daigler, 2014). The ability to behave rationally has been addressed extensively in the literature, especially since rational decisionmaking is a key assumption in most economic and financial models. Dearden 
(2019) describes the manner in which heuristics and biases, which have an adverse effect on rational decision-making, could promote criminal economic activity. For example, it may be reasonably assumed that an optimism bias would have a disruptive effect on decision-making by white-collar offenders, especially in times of stress, since it is sustained by the difficulty in exposing such offences and the considerable time that elapses from the moment of its discovery to the taking of punitive action. Rub (2017), who investigated senior officers convicted of financial crimes using the intuitive decision-making questionnaire based on the theory of Kahneman \& Tversky (1973), came to the conclusion that the officers made decisions based more on intuition and gut feeling, and less on rational thinking. Soltes (2016), who carried out a qualitative research study in which he interviewed senior managers who had been convicted of financial crimes, reached a similar conclusion.

\subsection{Traits as Predictors of Financial Delinquency}

There is a lack of studies on the personality traits of individuals who are attracted to and work in the financial sector. Tauni et al. (2019) examined connection between the big five (personality) attributes of investors and their agents on the one hand, and their behaviour in the business world on the other. Notable attempts were made recently to associate traits such as psychopathy, narcissism and Machiavellianism (the "dark triad") in people working in the field of finance with the possibility that these traits spur financial crime (Babiak \& Hare, 2006; Bailey, 2017; Majors, 2016; Murphy, 2012).

With regard to psychopathy (Trompeter et al., 2013), the new definitions revert to the original one (Cleckley, 1941) and take into account characteristics such as sociability (personal charisma, initiative, intelligence), while placing less emphasis on past criminal behaviour (Cooke et al., 2007). It is estimated that up to $20 \%$ of senior personnel in financial organizations exhibit this disorder (Babiak et al., 2010; Fritzon et al., 2017), in contrast to $1 \%$ in the population as a whole (Neumann \& Hare, 2008).

One type of this disorder includes pathological liars (Nee et al., 2019), who succeed to a certain extent in concealing their negative attributes, exhibit control over their impulses, and convey an impression of being normal and successful. They use their talents manipulatively, devoid of compassion, guilt or empathy. These individuals do not accept responsibility for their actions (Wall et al., 2015). It is possible that the findings of previous research studies, which did not take such traits into account, missed identifying this personality disorder among white-collar felons (Rolseh et al., 2017). Thus, with the exception of isolated studies (e.g. Ray \& Jones, 2011), there is a paucity of knowledge regarding the relationship between this type of psychopathy and white-collar crime.

Narcissism typifies individuals with a mania for succeeding and a capacity for careening into antisocial behaviour (Bromberg, 1965). They are driven by an overwhelming need to prove to the world that they are worthy and special (owning 
the most beautiful home, the most flourishing business, etc.), without which they experience emptiness and failure. The more intense the disorder, the greater is the thirst for achievement and the more serious the danger of crossing the line into antisocial conduct, with the attendant search for immediate gains (Egan et al., 2015; Jones et al., 2017).

The Dark Triad. Recent studies have focused on correlations between the characteristics of the so-called dark triad-psychopathy, narcissism and Machiavellianism (Babiak et al., 2010; Babiak \& Hare, 2006; Hare, 1993; Paulhus \& Williams, 2002; Tang et al., 2008; Trompeter et al., 2013)—and white-collar crime. Research has found high level of narcissism among white-collar offenders (Blickle et al., 2006; Bromberg, 1965; Hogan \& Hogan, 2001).

The majority of the empirical work in this realm has been focused on psychopathy. The type of psychopathy found to be associated with white-collar offences (Alalehto \& Azarian, 2018; Collins \& Schmidt, 1993) is manifested in a dubious life style, impulsiveness, outbreaks of violence, risk-taking and antisocial leanings (Hare \& Neumann, 2010), with no acceptance of responsibility and no setting of long-term goals (Hare, 1994). Perri (2016) points to particularly dominant psychopathy in instances where white-collar offenders become red collar criminals (resorting to murder in response to a fear of exposure). He claims that the perception that white-collar offenders are not violent is mistaken (Perri, 2011). Alalehto \& Azarian (2018) and Perri (2011) identify a subcategory of white-collar criminals who under certain conditions, especially when faced with the possibility of being tracked down, resort to violence or even murder.

Collins and Schmidt (1993) sampled 300 white-collar criminals and found evidence of a psychopathic tendency reflected in the absence of responsibility, unreliability and violation of norms. On the other hand, Blickle et al. (2006) found in Germany high level of hedonism, a search for thrills and a lack of selfcontrol, but higher conscientiousness in comparison to law-abiding directors in other companies. This finding is in line with that of another German study (Bresser, 1978, in Blickle et al., 2006) which found that white-collar felons are extremely persevering and target-oriented. High conscientiousness is in keeping with the image of rational, level-headed businessmen who wish to promote their own personal interests as well as those of their firm. According to this authors, white-collar offenders need high conscientiousness in order to fill senior managerial positions, and unlike managers who are non-offenders, have a high level of technological knowledge, aiding them in committing white-collar crimes based on the assumed low probability of being caught.

Ragatz and Fremouw (2010) conducted a meta-analysis of 16 research studies, deemed to meet validity requests that examined the psychological profiles of whitecollar criminals, and arrived at the conclusion that white-collar offenders are relatively low on the scale of social graciousness and self-control. The researchers noted that the chief limitations in the studies they examined were non-uniformity with respect to definitions and a lack of control over intervening variables (since comparison groups did not exist in every case). They recommended 
continuing with studies that will allow knowledge to be consolidated in the domain of therapy.

In addition to personality disorders, such as psychopathy, narcissism and Machiavellianism, which have the potential to cause a slide into criminality, it is proposed herein to examine a personality trait known as Type A, which includes characteristics of the three syndromes in the dark triad.

Differences in competitive orientations were examined in relation to two components of the Type A behavior pattern, Achievement Strivings and ImpatienceIrritability, that have differential implications for achievement performance and health. As expected, hyper-competitiveness was not related to Achievement Strivings, but positively correlated with Impatience-Irritability. In contrast, personal development competitiveness related positively to Achievement Strivings, but was not related to Impatience-Irritability (Jex et al., 2002; Thornton et al., 2011). Hyper-competitiveness was not related to actual academic achievement either, but personal development competitiveness was positively correlated. Hyper-competitiveness was associated with greater self-reported health problems, whereas personal development competitiveness was associated with fewer health problems. Results further corroborate the discriminant validity of the hypercompetitive and personal development competitive construct and suggest negative psycho-somatic implications for the hypercompetitive individual.

Type A-B. The Type A-B classification arose out of an attempt to correlate a psychological disposition with medical problems related to coronary artery disease (Jenkins et al., 1979). Reference is made to a connection between physical problems of type A individuals and fiercely ambitious and competitive personality, leading to feelings of stress and frustration. The opposite is true of Type B personalities, who are characterized by a balanced approach to professional and other challenges. These presumptions are supported by Jex et al. (2002). Thornton et al. (2011) exemplified the discriminant validity of hyper-competitiveness of Type A personae and personal development competitive construct and suggest negative psycho-somatic implications for hypercompetitive individuals. Bharati (2018) found that Type A personality (students) was positively correlated with different dimension of aggression while Type B personality was negatively correlated with different dimensions of aggression, with some moderating effect of socio-economic status. Accordingly, based on the moral modularity hypothesis (Wolf, 2001), it may be expected that a switch from a condition of relative levelheadedness to a willingness for risk-taking will be more acute in a Type A than in Type B individuals.

\subsection{Circumstantial Account}

For many years white-collar offences were treated as instrumental crimes (Friedrichs, 2009), involving considerations of profit and loss (Paternoster \& Simpson, 1993). The theory proposed by Cressey (1953), which gained the epithet "fraud triangle", was originally intended to account for offences related to fraudulent conduct, and recently extended to explain white-collar crime (Gottschalk, 
2015). The theory proposes a three-factor model, opportunity for delinquent decision, personal financial difficulty and rationalization. According to Wheeler (1990), white-collar crime takes place in times of distress and fear of financial collapse (e.g. Dearden, 2019). Recent studies have shown that in addition to opportunity, personality differences must be taken into account as an etiological basis for white-collar crime (Benson \& Manchak, 2014; Levi, 2013; Simpson, 2013). Bailey (2017) presents a unique combination of personality and circumstances in the context of white-collar crime, based on a model that combines psychopathy as a personality attribute in the fraud triangle (Cressey, 1953; Dorminey et al., 2012; Trompeter et al., 2013).

\subsection{Integrative Account: Predispositions and Circumstances}

Evidence may be found from the very origins of psychology as a legitimate branch of science for a distinction between two approaches to explain behaviour-primary traits or predispositions on the part of the individual (Funder, 2001; Sherman et al., 2010), and circumstantial factors (Funder, 2009; Reis, 2008). For much of the $20^{\text {th }}$ century, psychologists tended to apply only one of these approaches. In time, it became evident that a more valid account for behaviour could be achieved via models that combine elements from both approaches. Currently, it is difficult to find a non-overarched model in the majority of the fields of psychology.

The present study is deliberated to identify personality and circumstantial factors involved in financial crime. From the predisposition viewpoint the model focuses on differentiation between Type A and Type B individuals, while also investigating the relevance of the dark triad-psychopathy, narcissism and Machiavellianism - to this issue. Based on Cressey's (1953) fraud triangle, the three circumstantial factors on which the present study focuses are: the perpetrator's financial problems, the presence of an opportunity to commit "safe" theft, and the use of rationalization.

According to Hypothesis 1, there should be positive correlation between the three components of the fraud triangle-financial problems, opportunity and rationalization-and the Type A-B scale; the greater the relative importance assigned by financiers to financial problems, opportunity and rationalization, the higher should be the Type A-B score. According to Hypothesis 2, similar correlations are expected between the components of the fraud triangle and the scores of the dark triad.

\section{Method}

\subsection{Design Considerations}

Two categories of predisposition questionnaires were included in the overall design-Type A-B scale and the dark triad (psychopathy, narcissism and Machiavellianism). The circumstantial part of the model included the three components of Cressey's (1953) crime model—the perpetrator's financial problems, opportu- 
nity to commit a surreptitious risky act, and use of rationalization. The research generated data on each of these seven measures (four personality traits and three circumstantial factors) from each participant.

Type A-B predisposition was measured by a Hebrew version of the original questionnaire of Jenkins et al. (1979), prepared by Wolf (1983) and adapted in 2020 to the daily and professional routines of Israeli financiers. As for the three components of the circumstantial model, they were operationalized in terms of the Functional Theory of Cognition (Anderson, 1996, 2008, 2013) and its methodological counterpart, functional measurement (Anderson, 2001; Tevelev \& Wolf, 2019; Wolf, 2001). In the present context, this method intends to produce a quantitative representation of a functional cognitive schema, which assumingly represent the way in which the related three components which are included in Cressy's conception (the fraud triangle) are coded in terms of cognitive schemata. In the present context, this method necessitates coverage of all eight combinations of a three factorial model, where each factor has two degrees $(2 \times 2 \times 2=$ 8), as exemplified below.

\subsection{Participants}

The participants were 33 men, aged 22 to $76(M=45.23$; $S D=14.16)$, who held or had once held senior positions in the financial sector of public and private organizations in Israel. They belonged to a range of professions-economists, pension and investment agents, treasurers, and security traders. The participants were recruited via computer mediated social networks. Four of them were dropped out for calibration considerations.

\subsection{Tools and Procedure}

Each participant filled the predisposition questionnaires (Type A-B and the three dark triad components, the items of which are included in one questionnaire) and participated in a three-factorial (financial problems, opportunity and rationalization) experimental case study called "Functional Measurement" (The original data see in Appendix 1). Because of limitations due to the Covid-19 pandemic, these data was collected during one long phone conversation between the experimenter and each participant. The research process got underway after assurance of anonymity and a commitment to stop the procedure upon the participant's request.

One procedural issue should be addressed with regard to the decision to conduct phone mediated functional measurement. Unlike predisposition questionnaires (such as Type A-B and the dark triad), there is no precedence for functional measurement via the phone. That is because of the (traditional) dependence of measurement validity on face-to-face presence of the experimenter in a personal meeting with the participant. This is part of the reasons for the conventional categorization of functional measurement as a sort of experimental case study (Tevelev \& Wolf, 2019). Hence, the decision to conduct phone mediated 
functional measurement was hazardous, to say the least, since measurement validity depends on the construct validity of the results. In other words, it depends on the ability of the results to exhibit connections between predisposition measure(s) and circumstantial results.

As dictated by the three-factorial functional-measurement model $(2 \times 2 \times 2=$ $8)$, the participant was requested eight times to assess the likelihood ( $0 \%-100 \%)$ that a financier (hence a protagonist) will be tempted to make a delinquent decision. Such ratings were made in each of eight episodes on the basis of different combinations of the degrees of financial problem, opportunity and rationalization (yes/no), depending on the specific cell of the model. For instance, the protagonist has a financial problem, an opportunity for delinquent decision and a reasonable rationalization; or-the protagonist does not have a financial problem, has an opportunity for delinquent decision and a reasonable rationalization. To ensure that the participant relates to the three components of each of the model's eight cells, he was requested to describe these components in his own words and then instantly make the likelihood estimation (Tevelev \& Wolf, 2019). For sakes of clear and friendly presentation of this unique method, a detailed example in terms of demo results is presented below.

Following functional measurement (Anderson, 2001; Tevelev \& Wolf, 2019), the relative importance assigned by a (demo) participant to financial problem, opportunity and rationalization (hence $\mathrm{F}, \mathrm{O}$ and $\mathrm{R}$ ) are extracted from the original ratings, which are presented in Table $1 . \mathrm{F}$ is the mean difference between the two sets of four numbers each (yes/no), under the title "financial problem"; $F=(40+60+50+70) / 4-(20+30+30+40) / 4=55-25=30$. O is the mean difference between the two sets of four numbers each (yes - no), under the title "opportunity" (yes - no); $\mathrm{O}=(30+60+40+70) / 4-(10+40+20+$ $50) / 4=50-30=20 . \mathrm{R}$ is the mean difference between the two sets of four numbers each (yes - no), under the title "rationalization" (yes - no); $\mathbf{R}=(20+$ $40+50+70) / 4-(10+30+40+60) / 4=50-40=10$.

On this basis, the following computations yield the values of the relative importance (hence RI) assigned to each of the three schema components: RIf = $\mathrm{F} /(\mathrm{F}+\mathrm{O}+\mathrm{R})=30 /(30+20+10)=.50 ; \mathrm{RIo}=\mathrm{O} /(\mathrm{F}+\mathrm{O}+\mathrm{R})=20 /(30+20+10)$ $=.33 ; \mathrm{RIr}=\mathrm{R} /(\mathrm{F}+\mathrm{O}+\mathrm{R})=10 /(30+20+10)=.17$. Of course, these three ratios add to $1(100 \%)$. Such results, if were true, would reflect assignment of crucial relative importance to financial problem and, more than the importance assigned to opportunity and much more than the importance assigned to rationalization.

Table 1. Demo participant's estimations (Imaginary Financier).

\begin{tabular}{ccccc}
\hline Financial problem (F) & \multicolumn{2}{c}{ No } & \multicolumn{2}{c}{ Yes } \\
\hline Opportunity (O) & No & Yes & No & Yes \\
\hline Rationalization (R) & & & & \\
\hline Yes & 20 & 40 & 50 & 70 \\
No & 10 & 30 & 40 & 60 \\
\hline
\end{tabular}


After a short interval, the participant was asked to respond to the predisposition questionnaires, Type A-B and the dark triad (which had been sent to his email address).

With regard to the Type A-B questionnaire (Jenkins et al., 1979), which differentiates between two predispositions. Type A individual strives to maximize professional success whereas Type B person is more composed and willing to compromise. The Jenkins Activity Survey (JAS) contains 52 questions about being hard driving, competitive, setting quotas and deadlines for oneself. The higher the score the greater the A tendency, which is reflected in becoming impatient when others talk slowly, being quick and punctual, and having high activity and hostility level. Thus a predisposition of this kind in combination with circumstantial factors should be sufficient to explain and predict financial crime (Funder, 2001; Sherman et al., 2010).

In addition, personality questionnaires included in the dark triad (Paulhus \& Jones, 2011, Short Dark Triad SD3) - psychopathy, narcissism and Machiavellianism - were transmitted during the meeting. The inclusive questionnaire included 28 items, for which each participant was required to grade the extent to which he agrees with each claim, on a scale of 1 ("do not agree to a great extent") to 5 ("agree to a great extent"). The questionnaire comprised three components, with items 1 to 10 relating to Machiavellianism (statements such as: "It is wise to divulge your secrets to others" or "It is worth waiting for the right moment to get even with others"); items 11 to 19 referring to narcissism (statements such as: "Many group activities become boring if I don't take part in them", or "I know I am special because people tell me this all the time"); and items 20 to 28 referring to psychopathy (statements such as: "I love teasing 'losers"', or "It's true that I can be cruel"). An internal consistency test showed reasonable results for Machiavellianism ( $\alpha=.76)$, narcissism $(\alpha=.66)$ and psychopathy $(\alpha=.64)$.

\section{Results and Discussion}

Table 2 presents the correlations between all seven components of the overall design.

Table 2. Pearson correlation between all pairs of the study's factors.

\begin{tabular}{|c|c|c|c|c|c|c|c|c|}
\hline & $\mathrm{AB}$ & Financial difficulties & & Rationalization & Opportunity & Machiavellianism & Psychopathy I & Narcissism \\
\hline $\mathrm{AB}$ & & 1 & -.283 & -.227 & $.512^{\star x}$ & .113 & .282 & -.220 \\
\hline Financial difficulties & & & 1 & $-.544^{* *}$ & -.252 & .021 & -.126 & .093 \\
\hline Rationalization & & & & 1 & $-.674^{* x}$ & -.030 & -.083 & .044 \\
\hline Opportunity & & & & & & .016 & .207 & -.133 \\
\hline Machiavellianism & & & & & & & $.449^{*}$ & $.481^{\star *}$ \\
\hline Psychopathy & & & & & & & 1 & $.462^{*}$ \\
\hline Narcissism & & & & & & & & 1 \\
\hline
\end{tabular}

${ }^{*} p<.01,{ }^{* *} p<.05$. 
As a support for Cressey's (1953) circumstantial model, there are three noticeable correlations between its components. Financial problem is correlated negatively with rationalization and opportunity is correlated negatively with rationalization, $r=-.544$ and -.674 , respectively, $p<.01$ (two tailed Pearson). Possibly, the more severe the financial problem and the greater the opportunity the lesser the need for justification. In line with Hypothesis 1, Type A-B is correlated positively with opportunity, $r=.512, p<.01$. In other words, the higher the A-B score (Type A personality), the greater is the importance assigned to opportunity.

While there are no noticeable connections between the three components of Cressy's fraud triangle and the dark triad, the positive correlations between the triad's components seem to provide some validation for this construct: Machiavellianism is correlated with psychopathy and with narcissism, $r=.449$, and .481 , respectively, $p<.05$, and narcissism is correlated with psychopathy, $r=.462, p$ $<.01$.

\section{General Discussion}

The findings point to the possibility that Type A individuals in charge of monetary operations of an organization assign relatively high importance to opportunities to make delinquent decisions in cases of financial problems. No support was obtained for the presumed relevance of the dark triad to this dispositioncircumstances connection. Interrelationships were found between the components of the dark triad, a fact that would support the supposition that the three components of the dark triad should be considered a valid construct. However, this (lack of) finding necessitates a recommendation not to include this construct in future studies purported to form an overarched account for financial delinquency.

From a methodological perspective, because of the Corona epidemic the study took place (individually) via the telephone. This sort of experimenter-participant communication is unprecedented, especially for Functional Measurement (Anderson, 2001), the methodological counterpart of the Functional Theory of Cognition, which is a sort of experimental case study (Tevelev \& Wolf, 2019; Wolf, 2001). Thus far, the very many experiments within this framework were frontal. To make this nearly impossible task possible, the experimenter (a female graduate student, formerly an experienced private detective) had to use unusual means to convince financiers to serve as participants. She established warm and pleasant rapport with each participant. She responded promptly to any sign of participants' loss of concentration' and gave them breaks, which were required to regain concentration along the prolonged session. A recommendation to establish a routine procedure of telephone or computerized mediated functional measurement is implied. Such a methodological development looks almost necessary in Corona conditions, and possibly in conditions of post Corona as well.

Further research in the line of the present study should help in focusing its 
scope, especially in terms of the professional affiliation of the participants. For instance, the present participants were normative financiers. However, the target population of this issue is delinquent financiers. Assumingly, due to the unusual sophistication of such people, only some of them are captured and convicted. Thus, follow up (frontal, via telephone or computer mediated) studies should focus on prisoners and ex-prisoners with a background of financial delinquency.

The desired outcome of such research should be improvement of prevention and profiling. Prevention should gain from the combination (desirably integration) of the two complementary tools-predisposition questionnaires and circumstantial measures, such as Type A-B and Functional Measurement. On the basis of successful results of such research, it would be recommended that any new employee (and possibly old-timers) will be required to pass these two sorts of tests, the combined results of which can serve as a risk measure. These very tools can also serve for purposes of ad hoc identification of financial delinquents, i.e., profiling. The related data should be collected and analyzed, and the cumulating results should improve the prediction equation (forward and backward).

\section{Acknowledgements}

The authors wish to thank Dr. Eitan Nikotra and research assistants Shuval Gohrian and Eden Evenberg for their help in data collection through the forensic laboratory of the Department of Criminology, Ashkelon Academic College.

\section{Funding}

The authors disclosed receipt of the following financial support for the research, authorship, and/or publication of this article: This work was supported by Ashkelon Academic College, Israel.

\section{Conflicts of Interest}

The authors declare no conflicts of interest regarding the publication of this paper.

\section{References}

Alalehto, T., \& Azarian, R. (2018). When White Collar Criminals Turn to Fatal Violence: The Impact of Narcissism and Psychopathy. Journal of Investigative Psychology and Offender Profiling, 15, 215-226. https://doi.org/10.1002/jip.1503

Anderson, N. H. (1996). A Functional Theory of Cognition. Mahwah, NJ: Erlbaum.

Anderson, N. H. (2001). Empirical Decision in Design and Analysis. Mahwah, NJ: Erlbaum.

Anderson, N. H. (2008). Unified Social Cognition. New York: Psychology Press.

Anderson, N. H. (2013). Unified Psychology Based on Three Laws of Information Integration. Review of General Psychology, 17, 125-132. https://doi.org/10.1037/a0032921

Ashforth, B. E., \& Anand, V. (2003). The Normalization of Corruption in Organizations. Research Organization Behavior, 25, 1-52.

https://doi.org/10.1016/S0191-3085(03)25001-2 
Babiak, P., \& Hare, R. D. (2006). Snakes in Suites: When Psychopaths Go to Work. New York: Harper Business.

Babiak, P., Neumann, C. S., \& Hare, R. D. (2010). Corporate Psychopathy: Talking the Walk. Behavioral Science and the Law, 28, 174-193. https://doi.org/10.1002/bsl.925

Bailey, C. D. (2017). Psychopathy, Academic Accountants' Attitudes towards Unethical Research Practices, and Publication Success. The Accounting Review, 90, 1307-1332. https://doi.org/10.2308/accr-50970

Benson, M. L., \& Manchak, S. L. (2014). The Psychology of White-Collar Crime. In $O^{-}$ ford Handbooks Online in Criminology and Criminal Justice. New York: Oxford University Press. https://doi.org/10.1093/oxfordhb/9780199935383.013.008

Bharati, R. (2018). Socio-Economic Variables: A Contributing Factor for the Development of Aggressive Behavior among the Students with Type A and Type B Personality. Indian Journal of Community Psychology, 14, 125-132.

Blickle, G., Schlegel, A., Fassbender, P., \& Klein, U. (2006). Some Personality Correlates of Business White-Collar Crime. Applied Psychology: An International Review, 55, 220 233. https://doi.org/10.1111/j.1464-0597.2006.00226.x

Braithwaite, J. (1985). White-Collar Crime. Annual Review of Sociology, 11, 1-25. https://doi.org/10.1146/annurev.so.11.080185.000245

Bromberg, W. (1965). Crime and the Mind. New York: Macmillan.

Clarke, M. (1990). Business Crime: Its Nature and Control. New York: St Martin's Press.

Cleckley, H. (1941). The Mask of Sanity. St. Louis, MO: Mosby.

Collins, J. M., \& Schmidt, F. L. (1993). Personality, Integrity, and White-Collar Crime: A Construct Validity Study. Personnel Psychology, 46, 295-311. https://doi.org/10.1111/j.1744-6570.1993.tb00875.x

Cooke, D. J., Michie, C., \& Skeem, J. (2007). Understanding the Structure of the Psychopathy Checklist-Revised: An Exploration of Methodological Confusion. British Journal of Psychiatry, 190, s39-s50. https://doi.org/10.1192/bjp.190.5.s39

Cressey, D. R. (1953). Other People's Money: A Study in the Social Psychology of Embezzlement. Glencoe, IL: Free Press.

Dearden, T. E. (2019). How Modern Psychology Can Help Us Understand White-Collar Criminals. Journal of Financial Crime, 26, 61-73.

https://doi.org/10.1108/JFC-11-2017-0103

Dorminey, J., Fleming, A. S., Kranacher, M. J., \& Riley, R. A. (2012). The Evolution of Fraud Theory. Issues in Accounting Education, 27, 555-579.

https://doi.org/10.2308/iace-50131

Egan, V., Huges, N., \& Palmer, E. (2015). Moral Disengagement, the Dark Triad and Unethical Consumer Behavior. Personality and Individual Differences, 76, 123-128. https://doi.org/10.1016/j.paid.2014.11.054

Friedrichs, D. (2004). Enron et al.: Paradigmatic White-Collar Crime Cases for the New Century. Critical Criminology, 12, 113-132. https://doi.org/10.1023/B:CRIT.0000040258.21821.39

Friedrichs, D. O. (2007). Trusted Criminals. White-Collar Crime in Contemporary Society (3rd ed.). Belmont, CA: Thomson Wadsworth.

Friedrichs, D. O. (2009). Trusted Criminals: White-Collar Crime in Contemporary So$\operatorname{ciety}(4$ th ed.). Belmont, CA: Wadsworth Cengage.

Fritzon K., Bailey, C., Croom, S., \& Brooks, N. (2017). Problem Personalities in the Workplace: Development of the Corporate Personality Inventory. In P. A. Granhag, R. Bull, 
A. Shaboltas, \& E. Dozortseva (Eds.), Psychology and Law in Europe: When West Meets East (pp. 139-166). Boca Raton, FL: CRC Press.

Funder, D. C. (2001). Personality. Annual Review of Psychology, 52, 197-221. https://doi.org/10.1146/annurev.psych.52.1.197

Funder, D. C. (2009). Persons, Behaviors, and Situations: An Agenda for Personality Psychology in the Postwar Era. Journal of Research in Personality, 43, 120-126. https://doi.org/10.1016/j.jrp.2008.12.041

Gottschalk, P. (2015). Fraud Examiners in White-Collar Crime Investigations. Boca Raton, FL: CRC Press. https://doi.org/10.1201/b18495

Gottschalk, P. (2019). Offenders or Victims? Convenient Self-Portraits of White-Collar Criminals in Their Autobiographies. Pakistan Journal of Criminology, 11, 1-14.

Hare, R. D. (1993). Without Conscience. New York: The Guilford Press.

Hare, R. D. (1994). Predators: The Disturbing World of the Psychopaths among Us. Psychology Today, 27, 55-63.

Hare, R. D., \& Neumann, C. S. (2010). Psychopathy: Assessment and Forensic Implications. In L. Malatesti, \& J. McMillan (Eds.), Responsibility and Psychopathy: Interfacing Law, Psychiatry and Philosophy (pp. 93-123). Oxford: Oxford University Press. https://doi.org/10.1093/med/9780199551637.003.0007

Hartley, R. D. (2008). Corporate Crime: A Reference Handbook. Santa Barbara, CA: ABCCLIO.

Hogan, R., \& Hogan, J. (2001). Assessing Leadership: A View from the Dark Side. International Journal of Selection and Assessment, 9, 40-51. https://doi.org/10.1111/1468-2389.00162

Jenkins, C. D., Zyzanski, S. J., \& Rosenman, R. H. (1979). JAS Manual. New York, NY: The Psychological Corp.

Jex, S. M., Adams, G. A., Elacqua, T. C., \& Bachrack, D. G. (2002). Type A as a Moderator of Stressors and Job Complexity: A Comparison of Achievement Strivings and Impatience-Irritability. Journal of Applied Social Psychology, 32, 977-996. https://doi.org/10.1111/j.1559-1816.2002.tb00251.x

Jones, B. D., Woodman, T., Barlow, M., \& Roberts, R. (2017). The Darker Side of Personality: Narcissism Predicts Moral Disengagement and Antisocial Behavior in Sport. The Sport Psychologist, 31, 109-116. https://doi.org/10.1123/tsp.2016-0007

Kahneman D., \& Tversky, A. (1973). Availability: A Heuristic for Judging Frequency and Probability. Cognitive Psychology, 5, 207-232. https://doi.org/10.1016/0010-0285(73)90033-9

Levi, M. (2013). Individual Differences and White-Collar Crime. In F. T. Cullen, \& P. Wilcox (Eds.), Encyclopedia of Criminological Theory (pp. 469-473). Thousand Oaks, CA: Sage.

Lindström, D. (2004). Historical Perspectives: Swedish and International Examples. In H. Sjögren, \& G. Skogh (Eds.), New Perspectives on Economic Crime (pp. 128-157). Cheltenham: Edward Elgar Publishing.

Majors, T. (2016). The Interaction of Communicating Measurement Uncertainty and the Dark triad on Managers' Reporting Decisions. The Accounting Review, 91, 973-992. https://doi.org/10.2308/accr-51276

Mann, K. (1990). Special Characteristics of White-Collar Crime. Law Reviews, 15, 415421 (Hebrew, English abstract).

Murphy, P. R. (2012). Attitude, Machiavellianism and the Rationalization of Misreporting. Accounting, Organizations and Society, 37, 242-259. 
https://doi.org/10.1016/j.aos.2012.04.002

Nee, C., Button, M., Shepherd, D., Blackbourn, D., \& Leal, S. (2019). The Psychology of the Corrupt: Some Preliminary Findings. Journal of Financial Crime, 26, 488-495. https://doi.org/10.1108/JFC-03-2018-0032

Neumann, C. S., \& Hare, R. D. (2008). Psychopathic Traits in a Large Community Sample: Links to Violence, Alcohol Use and Intelligence. Journal of Consulting and Clinical Psychology, 76, 893-899. https://doi.org/10.1037/0022-006X.76.5.893

Paternoster, R., \& Simpson, S. (1993). A Rational Choice Theory of Corporate Crime. In R. V. Clarke, \& M. Felson (Eds.), Routine Activities and Rational Choice Theory (pp. 37-51). NJ: New Brunswick Transaction.

Patterson, F. M., \& Daigler, R. T. (2014). The Abnormal Psychology of Investment Performance. Review of Financial Economics, 23, 55-63.

https://doi.org/10.1016/j.rfe.2013.08.004

Paulhus, D. L., \& Jones, N. (2011). Introducing a Short Measure of the Dark Triad. Poster Presented at the Meeting of the Society for Personality and Social Psychology, San Antonio.

Paulhus, D. L., \& Williams, K. (2002). The Dark Triad of Personality: Narcissism, Machiavellianism, and Psychopathy. Journal of Research in Personality, 36, 556-568. https://doi.org/10.1016/S0092-6566(02)00505-6

Perri, F. S. (2011). White-Collar Criminals: The "Kinder, Gentler" Offender? Journal of Investigative Psychology and Offender Profiling, 8, 217-241. https://doi.org/10.1002/jip.140

Perri, F. S. (2016). Red Collar Crime. International Journal of Psychological Studies, 8, 61-84. https://doi.org/10.5539/ijps.v8n1p61

Ragatz, L., \& Fremouw, W. (2010). A Critical Examination of Research on the Psychological Profiles of White-Collar Criminals. Journal of Forensic Psychology Practice, 10, 373402. https://doi.org/10.1080/15228932.2010.489846

Ray, J. V., \& Jones, S. (2011). Self-Reported Psychopathic Traits and Their Relation to Intentions to Engage in Environmental Offending. International Journal of Offender Therapy, 55, 370-391. https://doi.org/10.1177/0306624X10361582

Reis, H. T. (2008). Reinvigorating the Concept of Situation in Social Psychology. Personality and Social Psychology Review, 12, 311-329. https://doi.org/10.1177/1088868308321721

Rolseh, A., Edens, J. F., \& Cox, J. (2017). Triarchic Model Personality Traits and Their Impact on Mock Juror Perceptions of a White-Collar Criminal Defendant. Journal of Personality Assessment, 99, 453-464. https://doi.org/10.1080/00223891.2016.1238830

Rub, J. (2017). Criminological Aspects of Reduction of White-Collar Criminality in Moldova and Israel: Criminal Behavior Approach. Thesis of Doctor of Philosophy in Law, Moldova: University of Moldova.

Sherman, R. A., Nave, C. S., \& Funder, D. C. (2010). Situational Similarity and Personality Predict Behavioral Consistency. Journal of Personality and Social Psychology, 99, 330-343. https://doi.org/10.1037/a0019796

Simpson, S. (2013). White-Collar Crime: A Review of Recent Developments and Promising Directions for Future Research. Annual Review of Sociology, 39, 309-331. https://doi.org/10.1146/annurev-soc-071811-145546

Soltes, E. (2016). Why They Do It? Inside the Mind of the White-Collar Criminal. New York: Public Affairs.

Sutherland, E. H. (1939). White-Collar Criminality. American Sociological Review, 5, 1-12. 
https://doi.org/10.2307/2083937

Tang, T. L., Chen, Y., \& Sutarso, T. (2008). Bad Apples in Bad (Business) Barrels: The Love of Money, Machiavellianism, Risk Tolerance, and Unethical Behavior. Management Decision, 46, 243-263. https://doi.org/10.1108/00251740810854140

Tauni, M. Z., Memon, A., Fang, H. X., Jebran, K., \& Ahsan, T. (2019). Influence of Investor and Advisor Big Five Personality Congruence on Futures Trading Behavior. Emerging Markets Finance and Trade, 55, 3615-3630.

https://doi.org/10.1080/1540496X.2019.1672529

Tevelev, V., \& Wolf, Y. (2019). Psycho Diagnosis in Terms of the Functional Cognitive Paradigm: An Integrative Complementary Framework. Cognition, Brain, Behavior, 23, 281-298.

Thornton, B., Thornton, R. M., \& Gold, J. A. (2011). Competitive Orientations and the Type A Behavior Pattern. Psychology, 2, 411-415.

https://doi.org/10.4236/psych.2011.25064

Trompeter, G. M., Carpenter, T., Desai, N., \& Riley, R. A. (2013). A Synthesis of FraudRelated Research. Journal of Practice and Theory, 32, 287-321. https://doi.org/10.2308/ajpt-50360

Wall, T. D., Wygant, D. B., \& Sellbom, M. (2015). Boldness Explains a Key Difference between Psychopathy and Antisocial Personality Disorder. Psychiatry Psychology and Law, 22, 94-105. https://doi.org/10.1080/13218719.2014.919627

Wheeler, S. (1990). White-Collar Crime: Findings from a Socio-Legal and Thought Research Program on the Problem of Motivation in White-Collar Crimes. Law Reviews, 15, 446-448. (In Hebrew)

Wolf, Y. (1983). Drivers' Detection of Danger Signals in Frustrating Conditions. Doctoral Dissertation, Ramat Gan, Israel: Bar-Ilan University.

Wolf, Y. (2001). Modularity in Everyday Life: Judgments of Aggression and Violent Behavior. Aggression and Violent Behavior, 6, 1-34. https://doi.org/10.1016/S1359-1789(99)00005-1

Xie, J. (2015). The Optimization of Judicial Rules on Anti-Insider Trading in China: Focusing on the Judicial Interpretation for the Crime of Insider Trading. International Journal of Law, Crime and Justice, 43, 151-193.

https://doi.org/10.1016/j.ijlcj.2014.08.001 


\section{Appendix 1}

Original Results in All Seven Factors.

\begin{tabular}{|c|c|c|c|c|c|c|c|c|}
\hline $\begin{array}{l}\text { Participant } \\
\text { No. }\end{array}$ & $\begin{array}{l}\text { Avg } \\
\text { A-B }\end{array}$ & $\begin{array}{l}\text { Personality } \\
\text { type }\end{array}$ & $\begin{array}{l}\text { Financial } \\
\text { problems }\end{array}$ & Rationalization & Opportunity & $\begin{array}{c}\text { Avg } \\
\text { Machiavellianism }\end{array}$ & $\begin{array}{c}\text { Avg } \\
\text { narcissism }\end{array}$ & $\begin{array}{c}\text { Avg } \\
\text { psychopathy }\end{array}$ \\
\hline 1 & 17.27 & A & 0.21 & 0.6 & 0.24 & 3.00 & 2.78 & 1.44 \\
\hline 2 & 16.46 & A & 0.31 & 0.3 & 0.40 & 3.70 & 3.89 & 3.33 \\
\hline 3 & 16.19 & A & 0.16 & 0.4 & 0.47 & 3.10 & 3.33 & 1.89 \\
\hline 4 & 16.05 & A & 0.24 & 0.4 & 0.41 & 2.90 & 3.22 & 1.33 \\
\hline 5 & 14.92 & A & 0.21 & 0.3 & 0.49 & 2.90 & 3.00 & 2.33 \\
\hline 6 & 14.68 & A & 0.16 & 0.3 & 0.55 & 2.60 & 2.44 & 1.67 \\
\hline 7 & 14.35 & A & 0.28 & 0.1 & 0.65 & 2.70 & 2.44 & 2.44 \\
\hline 8 & 14.19 & A & 0.21 & 0.5 & 0.32 & 2.00 & 2.33 & 1.00 \\
\hline 9 & 14.11 & A & 0.26 & 0.4 & 0.35 & 2.90 & 2.89 & 2.44 \\
\hline 10 & 14.08 & A & 0.35 & 0.3 & 0.39 & 2.80 & 3.00 & 1.44 \\
\hline 11 & 14.05 & A & 0.27 & 0.4 & 0.33 & 3.50 & 3.67 & 2.78 \\
\hline 12 & 14.03 & A & 0.41 & 0.2 & 0.40 & 2.90 & 3.22 & 2.33 \\
\hline 13 & 13.81 & A & 0.47 & 0.2 & 0.37 & 2.90 & 3.11 & 2.22 \\
\hline 14 & 13.73 & A & 0.31 & 0.2 & 0.45 & 2.00 & 3.11 & 1.33 \\
\hline 15 & 13.54 & B & 0.10 & 0.7 & 0.20 & 1.80 & 2.44 & 1.67 \\
\hline 16 & 13.46 & B & 0.39 & 0.5 & 0.14 & 2.70 & 2.89 & 2.22 \\
\hline 17 & 13.19 & B & 0.52 & 0.3 & 0.21 & 3.30 & 1.89 & 1.22 \\
\hline 18 & 12.95 & B & 0.33 & 0.4 & 0.27 & 3.60 & 3.44 & 1.67 \\
\hline 19 & 12.78 & B & 0.16 & 0.6 & 0.29 & 3.50 & 3.33 & 3.78 \\
\hline 20 & 12.46 & B & 0.41 & 0.4 & 0.20 & 2.80 & 2.89 & 3.33 \\
\hline 21 & 12.46 & B & 0.48 & 0.5 & 0.05 & 3.60 & 2.56 & 2.89 \\
\hline 22 & 12.24 & B & 0.10 & 0.9 & 0.04 & 2.10 & 2.78 & 2.00 \\
\hline 23 & 12.22 & B & 0.41 & 0.5 & 0.05 & 2.20 & 2.44 & 1.56 \\
\hline 24 & 12.16 & B & 0.20 & 0.6 & 0.17 & 3.70 & 3.00 & 2.56 \\
\hline 25 & 12.14 & B & 0.38 & 0.5 & 0.12 & 3.10 & 3.00 & 3.33 \\
\hline 26 & 11.86 & B & 0.61 & 0.1 & 0.29 & 1.90 & 2.78 & 2.22 \\
\hline 27 & 11.84 & B & 0.48 & 0.3 & 0.19 & 2.70 & 2.67 & 2.11 \\
\hline 28 & 11.68 & B & 0.16 & 0.5 & 0.39 & 3.20 & 2.56 & 1.78 \\
\hline 29 & 11.08 & B & 0.22 & 0.5 & 0.32 & 2.90 & 3.11 & 2.44 \\
\hline Total average & 13.59 & & 0.30 & 0.4 & 0.30 & 2.86 & 2.90 & 2.16 \\
\hline
\end{tabular}

